\title{
RISK ANALYSIS ASSOCIATED WITH VALUATION OF INDUSTRIAL PROPERTIES FOR BANKING PURPOSES
}

\author{
Ing. Pavel Krestes*1 \\ ${ }^{1}$ CTU in Prague, Faculty of Civil Engineering, Department of Applied Informatics, Thakurova 2077/7, \\ Prague 6, 160 00, Czech Republic, pavel.krestes@fsv.cvut.cz
}

\begin{abstract}
The way an investment is being financed presents one of the risks of investing in industrial properties, so extra attention should be paid to address this matter. Therefore, it is necessary to assess the property in terms of the risks that affects not only the market value of the property, but also the overall collateral and financing of the property. Banks set the level of risk for each property individually and there are several situations that may arise while assessing the risk. This paper discusses the risks associated with valuation of industrial properties for banking purposes.
\end{abstract}

\section{Keywords}

Risk analysis, industrial property, collateral, bank

\section{JEL Classification}

G32 Financing Policy • Financial Risk and Risk Management • Capital and Ownership Structure $\bullet$ Value of Firms $\bullet$ Goodwill

R33 Nonagricultural and Nonresidential Real Estate Markets

DOI: https://doi.org/10.14311/bit.2019.01.02

Editorial information: journal Business \& IT, ISSN 2570-7434, CreativeCommons license (c) (i) published by CTU in Prague, 2019, http://bit.fsv.cvut.cz/ 


\section{Introduction}

The property with high risk which is completely illiquid is viewed by the bank as an ineligible collateral. Another situation is a conditionally eligible collateral, that being if the property is eligible at the time of the assessment, but less risk is present, and the drawing of the loan is conditional on eliminating these risks. The last situation is where the property is without risks and in this case it is a eligible collateral. Therefore, it can be said, that the property is, according to the eligibility, divided from the bank's point of view as eligible, conditionally eligible and ineligible collateral.

\section{Risk identification}

Below is a breakdown of the risks according to their impact on the eligibility of the collateral.

\section{Eligible collateral - low risk}

The properties where no risk is identified, i.e. meets the following requirements:

- The property is registered in Cadaster of Real Estate.

- Legal status of the property corresponds to the actual state.

- Access to the property is possible from public road.

- The property is in complete ownership.

- The property is free of any encumbrances, such as pledges, creditor's claims, servitudes or easements.

- The property is in good technical condition.

- The property is connected to utilities, or the connection to utilities is legally secured.

- The properties (such as buildings, lands) are in functional unit.

- The property is free of any unfavorable lease agreements. [2]

\section{Conditionally eligible collateral - medium risk}

There are risks that exclude property as an eligible collateral but they can be removed in real time without high financial costs. Once the risks are eliminated, the property becomes eligible for securing the loan. The most common risks are:

- The use of the property is limited by encumbrances, such as pledges, creditors claims, servitudes or easements.

- The property is not properly registered in Cadaster of Real Estate.

- The property has multiple owners.

- Access to the property is not legally secured.

- Connection to utilities is not legally secured. [2]

\section{Ineligible collateral - high risk}

In this section are properties where is identified serious risks, such as property in very poor technical condition, land that is ecologically degraded, military structures, church buildings, civil facilities etc. The most common risks are:

- The property is not registered in Cadaster of Real Estate and registering is not possible.

- The property has no access.

- Co-ownership of the property.

- The property is located in an ineligible location (e.g. areas of flood hazard, undermined areas).

- The property has a demonstrable impact on environmental pollution. 
- The property is in very poor technical condition.

- Unfavorable lease agreements. [2]

\section{Risk assessment}

Risk assessments and their impact on the value of a property always depend on the appraiser, the bank's methodology, and individual approach to the property. If the risk is appreciable, it is deducted from the property value, but some risks are not taken into account, for example, the appraiser only informs the bank of their occurrence. Consequently, it is up to the bank to assess whether the property is a eligible collateral.

Subsequently, it will be assessed how these risks affect the value of the property and thus the financing of the property. The following risk analysis is carried out by the semi-quantitative PNH method, where the risk will be assessed with regard to the likelihood of the risk, the probability of consequences and the impact of the risk.

The probability estimate $(P)$ is determined according to the probability estimation scale from 1 to 5 , where the degree, level and criteria of each risk is simplified. The probability determination of consequences $(\mathrm{N})$ is also on a scale of 1 to 5 , as well as the item $(\mathrm{H})$, which takes into account the degree of severity or the impact on the overall process. [1]

Table 1 - PNH Method estimation scale ([1], own source)

\begin{tabular}{|l|l|} 
P & \\
\hline At random & 1 \\
\hline Unlikely & 2 \\
\hline Probably & 3 \\
\hline Very likely & 4 \\
\hline Permanently & 5 \\
\hline
\end{tabular}

$\mathrm{N}$

\begin{tabular}{|l|l|}
\hline The property is eligible collateral & 1 \\
\hline
\end{tabular}

\begin{tabular}{|l|l|}
\hline The property is eligible collateral subject to the removal of minor risks & 2 \\
\hline
\end{tabular}

\begin{tabular}{|l|l|}
\hline The property is conditionally eligible collateral with short process of risk elimination & 3 \\
\hline
\end{tabular}

\begin{tabular}{|l|l|}
\hline The property is conditionally eligible collateral with long process of risk elimination & 4 \\
\hline
\end{tabular}

\begin{tabular}{|l|l}
\hline The property is ineligible collateral & 5 \\
\hline
\end{tabular}

$\mathrm{H}$

\begin{tabular}{|l|l|}
\hline Negligible influence on the eligibility of collateral & 1 \\
\hline
\end{tabular}

\begin{tabular}{|l|l}
\hline Small influence on the eligibility of collateral & 2 \\
\hline
\end{tabular}

\begin{tabular}{|l|l|}
\hline Medium influence on the eligibility of collateral & 3 \\
\hline
\end{tabular}

\begin{tabular}{|l|l|l|l}
\hline Big and significant influence on the eligibility of collateral & 4 \\
\hline
\end{tabular}

\begin{tabular}{|l|l|}
\hline More significant and adverse effects on the eligibility of collateral & 5 \\
\hline
\end{tabular}

The risk level assessment is as follows, which are recorded in columns $\mathrm{P}, \mathrm{N}$ and $\mathrm{H}$ in the table. The overall risk assessment $\mathrm{R}$ is then:

$$
\mathrm{R}=\mathrm{P} \times \mathrm{N} \times \mathrm{H}
$$


Table 2 - Risk level [1]

\begin{tabular}{|l|l|l|}
\hline Risk grade & R & Risk level \\
\hline I & $>100$ & Unacceptable risk \\
\hline II & 51 to 100 & Undesirable risk \\
\hline III & 11 to 50 & Slight risk \\
\hline IV & 3 to 10 & Acceptable risk \\
\hline V & $<3$ & Insignificant risk \\
\hline
\end{tabular}

\section{Example of risk assessment - model situation}

Possible risks were mentioned at the beginning of this paper. Below is an individual severity evaluation of the risk and also practical application of this evaluation method to the property samples.

Table 3 - Risk identification and assessment (own source)

\begin{tabular}{|l|l|l|l|l|l|}
\hline \multirow{2}{*}{$\begin{array}{l}\text { Risk } \\
\text { number }\end{array}$} & \multirow{2}{*}{ Risk identification } & \multicolumn{4}{|l|}{ Risk severity assessment } \\
\cline { 3 - 7 } & & P & N & H & R \\
\hline 1 & the use of the property is limited by easement & 4 & 2 & 3 & 24 \\
\hline 2 & the property is not registered in the Cadaster of Real Estate & 3 & 2 & 3 & 18 \\
\hline 3 & property has more co-owners & 4 & 2 & 2 & 16 \\
\hline 4 & the property is encumbered by a pledge of another bank & 4 & 3 & 3 & 36 \\
\hline 5 & access to the property is not legally secured & 3 & 3 & 3 & 27 \\
\hline 6 & sealing in title deed & 2 & 2 & 2 & 8 \\
\hline 7 & unresolved legal relationship in Letter of Ownership & 2 & 2 & 2 & 8 \\
\hline 8 & connection to utilities is not legally secured & 3 & 3 & 3 & 27 \\
\hline 9 & $\begin{array}{l}\text { property is not registered in Cadaster of Real Estate and } \\
\text { registering is not possible }\end{array}$ & 2 & 5 & 5 & 50 \\
\hline 10 & property has no access & 3 & 4 & 4 & 48 \\
\hline 11 & co-ownership share of the property & 3 & 4 & 4 & 48 \\
\hline 12 & $\begin{array}{l}\text { property is located in an ineligible location (e.g. areas of flood } \\
\text { hazard no. } 3 \text { and no. 4, undermined areas) }\end{array}$ & 3 & 5 & 5 & 75 \\
\hline 13 & $\begin{array}{l}\text { property has a demonstrable impact on environmental } \\
\text { pollution }\end{array}$ & 1 & 5 & 4 & 20 \\
\hline 14 & property is intended to demolition & 2 & 5 & 5 & 50 \\
\hline 15 & property is in poor technical condition & 3 & 5 & 5 & 75 \\
\hline
\end{tabular}

In the figure below we can clearly see which identified risk is most undesirable. 
Overall risk assessment - $\mathrm{R}$

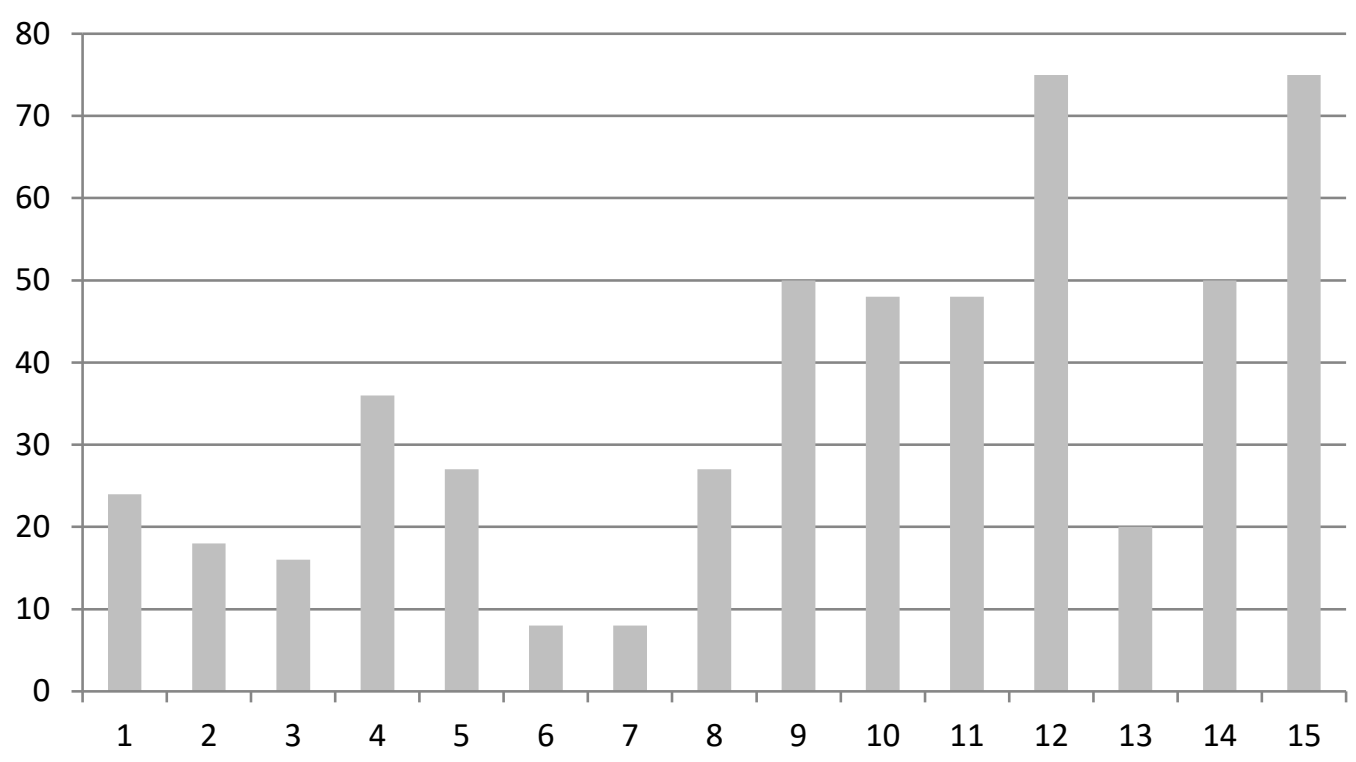

Figure 1 - Overall risk assessment R

Three fictitious properties with different risks were used as model situations. Subsequently, the properties were assessed according to the risk levels of the risk analysis using the PNH method.

Table 4 - Property No. 1 (own source)

\begin{tabular}{|l|l|}
\hline \multicolumn{2}{|l|}{ Property identification } \\
\hline Basic parameters & Mladá Boleslav \\
\hline Location & 230,00 \\
\hline Office floor area [m2] & 2250,00 \\
\hline Warehouse floor area [m2] & excellently maintained \\
\hline Construction-technical condition & 2006 \\
\hline Year of construction & water, gas, electricity, sewage \\
\hline Utilities & \\
\hline Risks & by public communications \\
\hline Acces to the property & Properly \\
\hline $\begin{array}{l}\text { Registering in Cadaster of Real } \\
\text { Estate }\end{array}$ & \\
\hline $\begin{array}{l}\text { Encumbrances, such as pledges, } \\
\text { creditors claims, servitudes or } \\
\text { easements }\end{array}$ & no encumbrances \\
\hline Area of flood hazard & no. 1 \\
\hline Property value CZK & 35000 000,00 \\
\hline Current status & V \\
\hline RISK GRADE &
\end{tabular}

It follows from the above that the Property No. 1 is in risk grade $V$ and from the perspective of the bank it is a suitable collateral, the client would reach the required loan amount. 
Table 5 - Property No. 2 (own source)

\begin{tabular}{|l|l|}
\hline \multicolumn{2}{|l|}{ Property identification } \\
\hline Basic parameters \\
\hline Location & Praha 8 \\
\hline Office floor area [m2] & 180,00 \\
\hline Warehouse floor area [m2] & 1530,00 \\
\hline Construction-technical condition & well maintained \\
\hline Year of construction & 1998 \\
\hline Utilities & water, gas, electricity, sewage \\
\hline Risks & \\
\hline Acces to the property & by land of another owner, legally unsecured \\
\hline Risk grade & III \\
\hline Registering in Cadaster of Real Estate & Properly \\
\hline $\begin{array}{l}\text { Encumbrances, such as pledges, creditors } \\
\text { claims, servitudes or easements }\end{array}$ & Pledge \\
\hline Risk grade & III \\
\hline Area of flood hazard & no. 2 \\
\hline Property value CZK & \\
\hline Current status & 32 000 000,00 \\
\hline RISK GRADE & III \\
\hline
\end{tabular}

Property No. 2 is at risk level III due to poor access to property and pledge, and therefore it is conditionally eligible collateral. It would be up to the client to consider whether he would take a slight risk in deciding to invest in this property.

Table 6 - Property No. 3 (own source)

\begin{tabular}{|l|l|}
\hline \multicolumn{2}{|l|}{ Property identification } \\
\hline Basic parameters & \\
\hline Location & Rakovník \\
\hline Office floor area [m2] & 75,00 \\
\hline Warehouse floor area [m2] & 6500,00 \\
\hline Construction-technical condition & bad maintained \\
\hline Year of construction & 1970 \\
\hline Utilities & water, electricity, sewage \\
\hline Risks & \\
\hline Acces to the property sledges, & \\
\hline Registering in Cadaster of Real Estate & properly \\
\hline $\begin{array}{l}\text { Encumbrances, such as prvitudes or } \\
\text { creditor's claims, servich } \\
\text { easements }\end{array}$ & no encumbrances \\
\hline Area of flood hazard & no. 4 \\
\hline Property value CZK & \\
\hline Current status & 2500 000,00 \\
\hline RISK GRADE & II \\
\hline
\end{tabular}


Property No. 3 is due to the flood zone at risk level II, which is from the bank's point of view an undesirable risk and hence ineligible collateral.

\section{Conclusion}

It follows from the above, that when financing an industrial property, it is necessary to assess the potential risks associated with property. According to the assessment of the severity of the risk, it is clear that the worst possible risk is, among other things, the location of the property in flood zone no. 4 and poor construction and technical condition of the property. The elimination of flood risk is a very costly matter (e.g. construction of flood protection measures), so in this case it can be generally said that it is an ineligible investment. Other risks can be more or less secured, but it is always necessary to evaluate these risks and take action.

\section{References}

[1] KOUDELKA, C. a VRÁNA, V., Rizika a jejich analýza [Září 2006] [online]. Available from: http://fei1.vsb.cz/kat420/vyuka/Magisterske\%20nav/prednasky/web/RIZIKA.pdf.

[2] SKALICKÝ, M. Rizika spojená s oceňováním nemovitostí pro bankovní instituce. Brno: Vysoké učení technické v Brně, Ústav soudního inženýrství, 2014. Thesis supervisor Ing. Eva Vítková, Ph.D. 